\title{
Leaf functional trait variation in a humid temperate forest, and relationships with juvenile tree light requirements
}

\author{
Christopher H. Lusk ${ }^{\text {Corresp. } 1}$ \\ ${ }^{1}$ Environmental Research Institute, University of Waikato, Hamilton, New Zealand \\ Corresponding Author: Christopher H. Lusk \\ Email address: clusk@waikato.ac.nz
}

The species-rich arborescent assemblages of humid tropical forests encompass much of the known range of the leaf economics spectrum, often including $>20$-fold variation in leaf lifespan. This suite of traits underpins a life-history continuum from fast-growing pioneers to slow-growing shade-tolerant species. Less is known about the range of leaf traits in humid temperate forests, and there are conflicting reports about relationships of these traits with the light requirements of temperate evergreen angiosperms. Here I quantify the range of leaf functional traits in a New Zealand temperate evergreen forest, and relationships of these traits with light requirements of juvenile trees and shrubs. Foliage turnover of saplings of 19 evergreen angiosperms growing beneath gaps (12-29\% canopy openness) and in understories (1.2 - $2.9 \%$ ) was measured over 12 months. Dry mass per area (LMA), dry matter content, thickness, density and nitrogen content ( $N$ ) of leaves were also measured. Species minimum light requirements were indexed as the $10^{\text {th }}$ percentile of the distribution of saplings in relation to canopy openness. Interspecific variation of leaf lifespan was $\sim 6$-fold in gaps (0.6 to $3.8 \mathrm{yrs}$ ), and $\sim 11$-fold in the understorey ( 0.7 to $7.7 \mathrm{yrs}$ ). Six small tree and shrub species are effectively leafexchangers, with leaf lifespans of c.1 year in gaps-albeit usually longer in the shade. Interspecific variation in other leaf traits was 2.5 to 4 -fold. Lifespans and LMA of both sun and shade leaves were negatively correlated with species light requirements i.e. positively correlated with shade tolerance. However, light environment (gap vs shade) explained about the same amount of variation in LMA as species' identity did. Species light requirements were not significantly correlated with leaf $\mathrm{N}$, dry matter content, density or thickness-except for a marginally significant correlation with dry matter content of shade leaves. Species light requirements were thus less consistently related to leaf structural traits than appears to be the case in humid tropical forests. Whereas the wide interspecific variation in leaf economic traits of tropical rainforest species outweighs plastic response to light availability, temperate evergreen woody angiosperms appear to occupy a narrower 
range of the leaf economic spectrum. Standardization of the light environments in which LMA is measured is vital in comparative studies of humid temperate forest evergreens, because of countergradient responses of this trait to light, and because of the relative magnitudes of plastic and interspecific variation in LMA in these forests. 


\section{Leaf functional trait variation in a humid temperate forest, and relationships}

\section{2 with juvenile tree light requirements}

\section{Christopher H. Lusk}

5 Environmental Research Institute, University of Waikato, Private Bag 3105, Hamilton, New Zealand.

6 Email clusk@waikato.ac.nz

\section{Abstract}

8 The species-rich arborescent assemblages of humid tropical forests encompass much of the known

9 range of the leaf economics spectrum, often including $>20$-fold variation in leaf lifespan. This suite of

10 traits underpins a life-history continuum from fast-growing pioneers to slow-growing shade-tolerant

11 species. Less can be said with certainty about the range of leaf traits in humid temperate forests, and

12 there are conflicting reports about relationships of these traits with the light requirements of temperate

13 evergreen angiosperms. Here I quantify the range of leaf functional traits in a New Zealand temperate

14 evergreen forest, and relationships of these traits with light requirements of juvenile trees and shrubs.

15 Foliage turnover of saplings of 19 evergreen angiosperms growing beneath gaps ( $12-29 \%$ canopy

16 openness) and in understories (1.2 - $2.9 \%$ ) was measured over 12 months. Dry mass per area (LMA), dry

17 matter content, thickness, density and nitrogen content $(\mathrm{N})$ of leaves were also measured. Species

18 minimum light requirements were indexed as the $10^{\text {th }}$ percentile of the distribution of saplings in

19 relation to canopy openness. Interspecific variation of leaf lifespan was 6-fold in gaps (0.6 to 3.8 yrs),

20 and $\sim 11$-fold in the understorey ( 0.7 to $7.7 \mathrm{yrs})$. Six small tree and shrub species are effectively leaf-

21 exchangers, with leaf lifespans of $\sim 1$ year in gaps-albeit usually longer in the shade. Interspecific 
22 variation in other leaf traits was 2.5 to 4-fold. Lifespans and LMA of both sun and shade leaves were

23 negatively correlated with species light requirements i.e. positively correlated with shade tolerance.

24 However, light environment (gap vs shade) explained about the same amount of variation in LMA as species' identity did. Species light requirements were not significantly correlated with leaf $\mathrm{N}$, dry matter content, density or thickness - except for a marginally significant correlation with dry matter content of shade leaves. Species light requirements were thus less consistently related to leaf structural traits than appears to be the case in humid tropical forests. Whereas the wide interspecific variation in leaf economic traits of tropical rainforest species outweighs plastic response to light availability, temperate evergreen woody angiosperms appear to occupy a narrower range of the leaf economic spectrum. Standardization of the light environments in which LMA is measured is vital in comparative studies of humid temperate forest evergreens, because of countergradient responses of this trait to light, and because of the relative magnitudes of plastic and interspecific variation in LMA in these forests.

\section{Introduction}

The unrelenting evergreenness of humid tropical forests belies the vast range of foliage turnover rates revealed by comparative studies of their arborescent assemblages, which often exceeds 20-fold variation (Reich et al. 1991; Russo \& Kitajima 2016). This wide variation in leaf lifespan, closely linked to a suite of other leaf traits in what has become widely known as the "leaf economics spectrum", underpins a life-history continuum from fast-growing pioneers to slow-growing shade-tolerant species (Lohbeck et al. 2013; Poorter \& Bongers 2006; Sterck et al. 2006; Walters \& Reich 1999). This continuum is also associated with interspecific variation in wood density (King et al. 2006; van Gelder et al. 2006). The consistent picture emerging from studies of humid tropical forests is that low leaf mass per area (LMA), high assimilation rates and low wood density enable pioneer trees to rapidly pre-empt gaps and clearings, whereas positive long-term net carbon gain and survival under shade is made possible by 
robust, long-lived leaves, dense wood, and low respiration rates. The fast-growing pioneers that colonize gaps in humid tropical forests have "high-maintenance" foliage: their low-LMA leaves turn over rapidly (2 - 6 months) and have high rates of photosynthesis and respiration.

Less can be said with certainty about functional diversity of leaf traits in humid temperate forests, or about trait relationships with species' light requirements and life histories. Tall, fast-growing pioneers of the type found in tropical and subtropical humid forests are known to be lacking from mid-latitude forests (Lusk et al. 2011a). Seven-fold variation in leaf lifespans of juvenile trees has been reported from the humid temperate forests of south-central Chile (Lusk et al. 2008a), but fewer data are available from comparable assemblages in New Zealand and temperate Australia. In the deciduous angiosperm assemblages typical of continental temperate climates, interspecific differences in leaf lifespan are inevitably muted (van Ommen Kloeke et al. 2012; Walters \& Reich 1999). In evergreen temperate forests, leaf lifespan is once again consistently negatively correlated with species' reported light requirements (i.e. positively so with shade tolerance), but there is no such agreement about relationships of leaf structural traits such as LMA with light requirements (Fajardo \& Siefert 2016; Hallik et al. 2009; Lusk et al. 2011b; Lusk \& Warton 2007).

A lack of standardization of the light environments in which traits are measured might underlie some of the discrepancies in reporting relationships of leaf structural traits with light requirements of temperate forest evergreens (Keenan \& Niinemets 2016). LMA shows strong plastic responses to light availability, with sun leaves being much thicker than shade leaves of the same species (Poorter et al. 2009), and sometimes also denser. Plastic variation of LMA along light gradients thus runs counter to interspecific variation relating to species' shade tolerance (Lusk et al. 2010; Lusk et al. 2008b), with the result that sun leaves of light-demanding evergreens can have similar LMA to shade leaves of shade-tolerant species. If juvenile trees are sampled randomly or haphazardly without controlling for light environment, interspecific differences in traits such as LMA may be masked by plastic variation (Laughlin et al. 2017), 
as differential survival along light gradients results in light-demanding species being found on average in better-lit environments than their more shade-tolerant associates (Kobe 1999; Lusk et al. 2006; Poorter \& Arets 2003). The same biases may be present in databases compiled from reviews of the literature (see Keenan \& Niinemets 2016).

Here I document the range of leaf traits in a humid temperate forest arborescent assemblage in New Zealand, and relationships of these traits with species' light requirements. Leaf traits were measured in two distinct light environments (understorey shade and treefall gaps), using hemispherical photography to quantify canopy openness. It has recently been shown that the microclimates of clearings at the same site favour very different traits from those of species that regenerate primarily in treefall gaps (Lusk \& Laughlin 2017). The present study focuses mainly on species sorting along gap to understorey gradients, rather than the more open environments of clearings.

\section{Materials and methods}

\section{Study site}

The study was carried out in a humid temperate forest in the Lake Okataina Scenic Reserve $\left(38.08^{\circ} \mathrm{S}\right.$, $176.42^{\circ} \mathrm{E}$ ), in the North Island of New Zealand. Sampling was carried out in a 300 ha basin lying at about $400 \mathrm{~m}$ a.s.l. within the reserve, infilled with tephras (mainly rhyolitic) derived from the Okataina Volcanic Centre (Pullar et al. 1973). Climate data from GIS layers indicate a mean annual temperature of $11.7^{\circ} \mathrm{C}$, a frost-free period of 195 days, and mean annual precipitation of 1659 mm (IIASA/FAO 2012; Landcare Research 2011). Rainfall is evenly-distributed throughout the year. Although juvenile trees growing in clearings are exposed to large vapour pressure deficits ( $>1.5 \mathrm{kPa}$ ) during dry spells, deficits of that magnitude have not been recorded in the understorey and tree-fall gap environments where traits were measured in the present study (Lusk \& Laughlin 2017). A research permit to work the site (66760-RES) was obtained from Department of Conservation. 
92 The disturbance history of the basin has created a complex vegetation mosaic, including a wide range of

93 light environments (Lusk \& Laughlin 2017). Most of the basin remains in tall forest with a canopy

94 dominated by Beilschmiedia tawa (Lauraceae) up to $30 \mathrm{~m}$ tall and scattered emergent conifers up to

95 45m, mainly Dacrydium cupressinum and Dacrycarpus dacrydioides (Podocarpaceae). Conifers occurred

96 at higher densities before selective logging during the mid-20 ${ }^{\text {th }}$ century (Nicholls 1991); this history of

97 logging has left behind several clearings and a network of skidder tracks, some of which have been

converted to walking tracks. At the north end of the basin is a stand of $<2$ ha with a canopy dominated

by Weinmannia racemosa (Cunoniaceae), which admits more light to the understorey than the deep-

crowned B. tawa that predominates elsewhere (Beveridge 1973). As a result, seedlings and saplings of a

wide range of species can be found in the understorey of this stand, which presumably owes its origin to

a small fire or wind damage. All native tree and shrub species present in the basin are evergreen, except

for Fuchsia excorticata (Onagraceae) and very occasional Plagianthus regius (Malvaceae) - McGlone et

al. (2004) describe both as deciduous, but report that some northern populations of the former retain

some leaves during winter.

\section{Measurements of leaf traits}

I measured a range of leaf traits that have variously been shown to correlate with species' light requirements in other evergreen forests (Kitajima \& Poorter 2010; Lusk et al. 2010; Poorter \& Bongers 2006). Although leaf mass per area (LMA) is the structural trait included in the original leaf economic spectrum concept (Reich et al. 1991; Wright et al. 2004), it can be informative to partition this trait into leaf thickness and density-it has been reported that density correlates strongly with species' shade tolerance in tropical humid tropical forests, whereas thickness does not (Kitajima \& Poorter 2010).

113 Accordingly, leaf density and thickness were measured in addition to LMA. Leaf dry matter content is a widely used alternative to LMA, and has also been found to correlate with species' light requirements in

115 some humid forests (Lusk et al. 2010; Poorter 2009). 
116 Two ranges of light environments were defined as sources of sun- and shade-leaf traits (Tables 1, 2).

117 Sun-leaf traits were measured on plants growing beneath tree-fall gaps, or besides roads or walking

118 tracks. Shade-leaf traits were measured on juvenile trees growing mostly in the understorey of the $W$.

119 racemosa-dominant stand at the north end of the basin. In each of these two light environments, five to

120 six juveniles (50-200 cm tall) were selected haphazardly for leaf trait measurements. A Nikon Coolpix

1214500 digital camera (Nikon, Tokyo, Japan) and an EC-08 fisheye adaptor were used to take a photo

122 immediately above the apex of each of these selected juveniles (as described above), and Gap Light

123 Analyzer (Frazer et al. 1999) was used to estimate \% canopy openness from each photo. Light

124 environments above plants sampled in gaps ranged from 12.0 to $27.8 \%$ canopy openness, compared to

1251.2 to $3.0 \%$ in the understorey. There was no significant interspecific variation in mean canopy

126 openness above plants sampled in either gaps (ANOVA, $P=0.97$ ) or shade $(P=0.76)$. Juveniles of

127 Coprosma robusta could not be found in understorey environments comparable with those of the other

128 species, so C. robusta was sampled only in gap environments.

129 Leaf lifetimes were estimated by following survival of leaves over a 12-month period. The height of the

130 principal axis of each juvenile was measured to the apex, and all fully-expanded leaves on this axis were

131 counted. Twelve months later, each plant was revisited, its height remeasured, and survival of leaves

132 recorded. Abscission scars were counted to determine mortality of new leaves initiated after the start of

133 the study period; this was important for species that turn over most or all of their foliage in a single

134 year, such as Aristotelia serrata.

135 Leaf lifetime (years) was estimated as:

136

$$
\frac{n^{i}}{\left(n^{i}-n^{f}\right)+m^{n}}
$$


137 where $n_{i}=$ initial number of leaves, $n_{f}=$ final number surviving from $n_{i}$, and $m_{n}=$ mortality of new leaves

138 initiated since the first census (King 1994; Lusk et al. 2008a). A few of the marked plants either suffered

139 major damage by herbivores or disturbance during the study, or could not be relocated, and leaf

140 lifespan estimates were eventually obtained from four to five plants of each species in each light

141 environment.

142 After leaf lifespan measurements, leaves were taken from each of the same plants, for measurement of

143 sun- and shade-leaf structural traits. Depending on leaf size, one to 10 of the youngest fully-expanded

144 intact leaves were taken from each plant, avoiding leaves damaged by herbivores. Leaves were placed

145 immediately in re-sealable plastic bags with moist tissue paper, and fresh weight determined within six

146 hours of removal. Fresh leaves were photographed, and area calculated using ImageJ software

147 (Schneider et al. 2012). Leaf volume was estimated using Archimedes' principle. The leaf was immersed

148 in a small container of water placed on an electronic balance, and displaced volume determined from

149 the change in apparent weight. A small amount of detergent was added to the water to reduce

150 hydrophobicity of leaf surfaces, and reduce bubble formation. Leaf thickness was later estimated

151 dividing volume by area. Leaves were oven-dried at $60^{\circ} \mathrm{C}$ for three days before measuring dry weight;

152 drying was initiated within eight hours of leaf excision in all cases, minimizing the effect of dark

153 respiration on non-structural carbohydrates, which can contribute up to $25 \%$ of leaf dry mass (Lusk \&

154 Piper 2007). Leaf density was then calculated as dry mass / fresh volume. Leaf samples were pooled to

155 obtain one estimate of total nitrogen content of each species in each light environment, using the

156 Dumas combustion method.

\section{Quantifying species light requirements}

158 Distributions of juvenile trees $50-200 \mathrm{~cm}$ tall were quantified in relation to canopy openness

159 determined from hemispherical photographs. Sampling was carried out on a series of transects run 
160 through old-growth stands, including tree-fall gaps of varied sizes and forest margins. Sets of parallel

161 transects were run through forest stands, spaced at least $20 \mathrm{~m}$ apart, A total of 748 points were sampled

162 at random intervals (10 to $15 \mathrm{~m}$ apart) along transects. Presence of juvenile trees and shrubs $50-200 \mathrm{~cm}$

163 tall was recorded in a circular plot of 1-m diameter, centred on the sample point. Although multiple

164 juveniles of some species were often found in the same plot, only presence or absence data are used in

165 the present analysis. A Nikon Coolpix 4500 digital camera (Nikon, Tokyo, Japan) and an EC-08 fisheye

166 adaptor were used to take a photo at $1.5 \mathrm{~m}$ height at each sampling point. A spirit level fitted to the lens

167 cap was used to level the camera, and photos were taken mostly while the solar disc was either

168 obscured by clouds or below the horizon, to avoid errors caused by flaring and reflection. Gap Light

169 Analyzer (Frazer et al. 1999) was used to estimate \% canopy openness from each photo.

170 The $10^{\text {th }}$ percentile of the distribution of each species in relation to canopy openness was used as an

171 approximation of the lowest light levels tolerated by each species (Lusk et al. 2008a). This parameter is

172 referred to hereafter as minimum light requirements (MLR). MLR represents an inversion of traditional

173 shade tolerance ratings, i.e., shade-tolerant taxa have low MLRs, and light-demanders score high. Only

174 species represented on at least 15 sampling plots were considered, yielding 18 species (Table 1).

\section{Statistical analyses}

176 One-way ANOVA was used to test for interspecific variation in the light environments in which leaf traits

177 were measured. All trait data except leaf dry matter content were $\log _{10}$-transformed before analysis, in

178 order to meet the assumption of additivity of effects (Quinn \& Keough 2002). The field sampling

179 procedure meant light environments were effectively nested within species, as species were not all

180 compared in common plots using a full factorial design. Nested ANOVA were therefore used to test for

181 leaf trait differences between sun and shade leaves, and among species. In addition to cross-species

182 correlations, relationships among leaf traits and species light requirements were also measured using

Peer] reviewing PDF | (2018:08:30381:2:0:NEW 8 Mar 2019) 
183 phylogenetic least squares regression (PGLS: Symonds \& Blomberg 2014), to take into account the

184 influence of phylogeny on trait relationships. COMPARE 4.6 (Martins 2004) was used to carry out PGLS

185 contrasts. A fully-resolved tree of the 19 species was obtained from the Angiosperm Phylogeny Group

186 website (Stevens 2001), although the lack of Coprosma robusta in the understorey meant only 18

187 species were included in the analysis of shade leaf traits. All other analyses were carried out in Statistica

188 (Stat Soft. Inc., Tulsa, OK 74104, USA)

\section{Results}

\section{Inter- and intraspecific variation in leaf traits}

191

192

193

194

195

196

197

198

199

200

201

202

203

204

ANOVA showed highly significant interspecific variation in all traits, as well as highly significant effects of light environment on all traits except for leaf density, which was only marginally affected by light (Table 3). ANOVA of leaf $\mathrm{N}$ data was not possible, due to the lack of replication resulting from pooling of leaf samples.

Interspecific variation of most traits was more marked in shade leaves than in sun leaves. This was especially true of leaf lifespan, which ranged 0.6 to 3.8 years in gaps, and 0.7 to 7.7 years in the understorey (Table 2). Other traits showed narrower ranges of values, spanning 2.4- to 3-fold variation in gaps, and 2.5- to 3.9-fold variation in the understorey.

Leaf lifespan was the trait that responded mostly strongly to light, shade leaves on average living about $70 \%$ longer than sun leaves of the same species (Table 2). LMA also responded strongly to light, leaves from plants growing in gaps on average having $58 \%$ more dry mass per area than shade leaves of the same species (Table 2); light environment explained just as much variation in LMA as species identity did (Table 3). Light environment had least effect on leaf density and leaf dry matter content, which respectively averaged only 10 and $11 \%$ higher in gap plants than in understorey conspecifics; variation 
205 in these two traits was therefore dominated by the effect of species (Table 3). Leaf $\mathrm{N}$ of most species

206 was similar in the two light environments (Table 2).

207 Trait correlations with species' minimum light requirements

208 The three traits included in the original leaf economic spectrum (LMA, leaf $\mathrm{N}$, and leaf lifetimes) were

209 tightly coordinated in both sun and shade leaves (Kendall's coefficient of concordance $=0.78$ and 0.76

210 respectively, $\mathrm{P}<.0001 ;$ Fig. 1a. They showed varied correlations with the other traits making up the

211 dataset (Table 4).

212 Species' minimum light requirements ranged from 0.8\% (Beilschmiedia tawa) to 4.2\% (Coprosma

213 robusta) (Table 1). Species light requirements were strongly negatively correlated with leaf lifespans,

214 especially those of shade leaves (Table 4; Fig. 1c); leaf lifespan was thus positively correlated with

215 species' shade tolerance. Light requirements were also negatively correlated with LMA (Fig. 1b),

216 although this relationship was only marginally significant in gaps $(P=0.048)$ and non-significant

217 according to PGLS (Table 4). Light requirements were not significantly correlated with any other

218 structural trait or with leaf $\mathrm{N}$, except for a marginally significant correlation with dry matter content of

219 shade leaves under PGLS (Table 4).

220 Discussion

221 Leaf lifespans in the arborescent assemblage at Okataina spanned 6-fold interspecific variation in gaps,

222 and $~ 11$-fold in the understorey (Table 2). The absence from this temperate assemblage of the fast end

223 of the leaf trait spectrum found in humid tropical forests results in an approximate halving of the log-

224 scaled range of leaf lifespans found in the tropics. Some tropical pioneer trees turn over their foliage in

225 as little as two months (Poorter \& Bongers 2006; Reich et al. 1991; Williams et al. 1989), whereas the

226 shortest-lived leaves found in the assemblage at Okataina were those of Aristotelia serrata, which lived 
227 about 7 months on average in gaps, and about 8 months in the shade (Table 2). A. serrata is a small,

228 fast-growing tree associated mainly with treefall gaps and the edges of tracks at Okataina (Lusk \&

229 Laughlin 2017). Woody assemblages in temperate South America appear to span a similar range of leaf

230 economics to that found at Okataina, with no species reported as having a leaf lifespan of $<6$ months

231 (Damascos \& Prado 2001; Lusk \& Corcuera 2011; Lusk et al. 2011b). However, the few deciduous trees

232 present in both regions probably have slightly shorter leaf lifespans (e.g. Dungan et al. 2003). The

233 assemblage at Okataina did not include any species with the very high leaf nitrogen levels found in some

234 tropical pioneers (Poorter \& Bongers 2006; Reich et al. 1991), although comparable levels (c. 4\%) have

235 been reported from some New Zealand native leguminous trees not sampled at Okataina (McGlone et

236 al. 2004).

237 Species light requirements were less consistently related to leaf structural traits than appears to be the

238 case in humid tropical forests, despite strong relationships with leaf lifespan in both gaps and shade (Fig.

239 1). Although shade-tolerant evergreens in tropical and subtropical rainforests often have dense leaves

240 (Kitajima \& Poorter 2010; Lusk et al. 2010), light requirements of New Zealand temperate evergreens at

241 Okataina were only weakly (and non-significantly) correlated with density of shade leaves (Table 4), and

242 showed little relationship with that of sun leaves (Table 4). Notably, leaf densities of two relatively

243 shade-tolerant species (Laurelia novae-zelandiae and Hedycarya arborea) were among the lowest found

244 at Okataina ( $\leq 0.20 \mathrm{~g} \mathrm{~cm}^{-3}$ in both gaps and shade: Table 2). Species' light requirements were

245 significantly correlated with LMA, especially in the shade (Fig. 1a), in part reflecting the thickness of the

246 leaves of the two aforementioned shade-tolerant species (Table 2). However, the correlation with LMA

247 of sun leaves was weaker when phylogenetic relationships were taken into account by PGLS (Table 4).

248 The long leaf lifespans of $L$. novae-zelandiae and $H$. arborea probably depend to a high degree on

249 chemical (rather than physical) deterrence of herbivores, as both genera are known to be rich in

250 alkaloids and essential oils (Brophy et al. 2005; Leitão et al. 1999; Urzua \& Cassels 1978).

Peer] reviewing PDF | (2018:08:30381:2:0:NEW 8 Mar 2019) 
251 Standardization of the light environments in which LMA is measured may be especially important in

252 comparative studies of temperate evergreen assemblages. Not only does interspecific variation of LMA

253 in relation to light requirements run counter to plastic responses to light (as in other evergreen forests:

254 Lusk et al. 2008b), but the effect of light on LMA at Okataina was of similar size to that of species

255 identity (Table 3), reflecting a narrower range of the leaf economic spectrum than that present in the

256 arborescent assemblages of humid tropical forests. If this reduced range of leaf traits is typical of humid

257 temperate forest evergreen assemblages, lack of standardization of light environments in some studies

258 may thus explain the variety of reported relationships of LMA with light requirements of temperate

259 evergreen angiosperms, including relationships that are diametrically opposed to that reported here

260 (Fajardo \& Siefert 2016; Hallik et al. 2009). Leaf dry matter content and leaf density were less sensitive

261 than LMA to light environment, species' identity greatly exceeding the effect of light in explaining

262 variation in these traits (Table 3). However, leaf dry matter content and especially leaf density were less

263 useful indicators of shade tolerance than LMA, as they were only weakly related with species' light

264 requirements in the arborescent assemblage at Okataina (Table 4).

265 The ample representation of small trees with leaf lifetimes of about one year at Okataina (Table 2)

266 suggests the scarcity of the deciduous habit in the New Zealand flora is more a reflection of weak

267 seasonality than of soil fertility (cf. McGlone et al. 2004). Deciduous or semi-deciduous species account

268 for $<5 \%$ of New Zealand's woody flora (McGlone et al. 2004); this figure is very low in comparison with

269 temperate floras from continental climates of the northern hemisphere, but falls within the range of

270 values found in other oceanic temperate climates of the southern hemisphere-the proportion of (semi-

271 ) deciduous woody species in southern Chile is somewhat higher (c.8\%), but only a single deciduous tree

272 is native to Tasmania (Duretto 2009+). Although nutrient conservation is considered one of the

273 advantages of evergreenness (Aerts 1995), those evergreens that replace their entire canopies annually

274 (sometimes termed "leaf-exchangers") will be almost as nutrient-demanding as deciduous trees. Despite 
275 moderate soil C:N ratios and low total P at Okataina (Lusk et al. 2015), six of the 19 study species fit this

276 description, with leaf lifespans of 12-13 months in gaps (Table 3); these species retained their leaves

277 longer in the shade, ranging from a $27 \%$ increase in Brachyglottis repanda to a $100 \%$ increase in

278 Carpodetus serratus. Another species (Aristotelia serrata) turned over its foliage in well under a year in

279 both gaps and shade (Table 2). All of these seven species are small, fast-growing trees and shrubs that

280 are widespread throughout New Zealand, most of them associated with treefall gaps at Okataina (Lusk

281 \& Laughlin 2017),. Elsewhere, another New Zealand Coprosma species has also been found to turn over

282 its foliage in about one year (Richardson et al. 2010), as has the long-lived canopy tree Fuscospora fusca 283 (Wardle 1984).

\section{Conclusions}

This study makes two main contributions to the literature. Firstly, the dataset reported here-covering over half the arborescent assemblage at the site-confirms that humid temperate forests lack the fast end of the leaf economics spectrum found in their tropical counterparts, reflecting the absence of the fast-growing tall pioneers that exploit treefall gaps at low latitudes (Lusk et al. 2011a). Secondly, this study underlines the importance of standardizing the light environments in which leaf traits (especially LMA) of humid temperate evergreens are measured. Without standardization, the strong plastic response of LMA to light may mask interspecific variation in LMA associated with species' light requirements, which is less wide-ranging than in humid tropical forests. Insufficient standardization of light environments, coupled to countergradient variation in LMA (Conover \& Schultz 1995; Lusk et al. 2008b), may thus explain the lack of consistency in reported relationships of LMA with light requirements of temperate evergreen trees. 


\section{Acknowledgments}

297 I thank Tanja Lenz and Teruko Kaneko for technical assistance, and two anonymous reviewers for

298 comments that helped clarify some aspects of the manuscript.

\section{Literature cited}

300

301

302

303

304

305

306

307

308

309

310

311

312

313

314

315

316

317

318

319

320

321

322

323

324

325

326

327

328

Aerts R. 1995. The advantages of being evergreen. Trends in Ecology \& Evolution 10:402-407.

Beveridge AE. 1973. Regeneration of podocarps in a central North Island forest. New Zealand Journal of Forestry Science 18:23-35.

Brophy JJ, Goldsack RJ, and Forster PI. 2005. The leaf oils of the Australian species of Hedycarya (Monimiaceae). Journal of Essential Oil Research 17:432-436. 10.1080/10412905.2005.9698953.

Conover DO, and Schultz ET. 1995. Phenotypic similarity and the evolutionary significance of countergradient variation. Trends in Ecology \& Evolution 10:248-252.

Damascos MA, and Prado C. 2001. Leaf phenology and its associated traits in the winter-green species Aristotelia chilensis (Mol.) Stuntz (Elaeocarpaceae). Rev Chil Hist Nat 74:805-815.

Dungan RJ, Duncan RP, and Whitehead D. 2003. Investigating leaf lifespans with interval-censored failure time analysis. New Phytologist 158:593-600. 10.1046/j.1469-8137.2003.00772.x.

Duretto M. 2009+. Flora of Tasmania Online. (Tasmanian Herbarium, Tasmanian Museum \& Art Gallery: Hobart). Available at www.tmag.tas.gov.au/floratasmania.

Fajardo A, and Siefert A. 2016. Temperate rain forest species partition fine-scale gradients in light availability based on their leaf mass per area (LMA). Annals of Botany 118:1307-1315. 10.1093/aob/mcw184.

Frazer GW, Canham CD, and Lertzman KP. 1999. Gap Light Analyzer (GLA), Version 2.0: Imaging software to extract canopy structure and gap light transmission indices from true-colour fisheye photographs, users manual and program documentation. Simon Fraser University, Burnaby, British Columbia, and the Institute of Ecosystem Studies, Millbrook, New York.

Hallik L, Niinemets Ü, and Wright IJ. 2009. Are species shade and drought tolerance reflected in leaflevel structural and functional differentiation in Northern Hemisphere temperate woody flora? New Phytologist 184:257-274. 10.1111/j.1469-8137.2009.02918.x.

IIASA/FAO. 2012. Global Agro-ecological Zones (GAEZ v3.0). Available at http://gaez.fao.org/Main.html\# (accessed Nov 2016.

Keenan TF, and Niinemets Ü. 2016. Global leaf trait estimates biased due to plasticity in the shade. Nature Plants 3:16201. 10.1038/nplants.2016.201.

King DA. 1994. Influence of light level on the growth and morphology of saplings in a Panamanian forest. American Journal of Botany 81:948-957. 
King DA, Davies SJ, Tan S, and Noor NSM. 2006. The role of wood density and stem support costs in the growth and mortality of tropical trees. Journal of Ecology 94:670-680. 10.1111/j.13652745.2006.01112.x.

Kitajima K, and Poorter L. 2010. Tissue-level leaf toughness, but not lamina thickness, predicts sapling leaf lifespan and shade tolerance of tropical tree species. New Phytologist 186:708-721. 10.1111/j.1469-8137.2010.03212.x.

Kobe RK. 1999. Light gradient partitioning among tropical tree species through differential seedling mortality and growth. Ecology 80:187-201.

Landcare Research. 2011. Land Resource Information Systems Portal v1.0. Available at https://Iris.scinfo.org.nz/ (accessed 9 November 2018.

Laughlin DC, Lusk CH, Bellingham PJ, Burslem DFRP, Simpson AH, and Kramer-Walter KR. 2017. Intraspecific trait variation can weaken interspecific trait correlations when assessing the wholeplant economic spectrum. Ecology and Evolution 7:8936-8949. 10.1002/ece3.3447.

Leitão GG, Simas NK, Soares SS, de Brito APP, Claros BM, Brito TB, and Delle Monache F. 1999. Chemistry and pharmacology of Monimiaceae: a special focus on Siparuna and Mollinedia. Journal of ethnopharmacology 65:87-102.

Lohbeck M, Poorter L, Lebrija-Trejos E, Martínez-Ramos M, Meave JA, Paz H, Pérez-García EA, RomeroPérez IE, Tauro A, and Bongers F. 2013. Successional changes in functional composition contrast for dry and wet tropical forest. Ecology 94:1211-1216. doi:10.1890/12-1850.1.

Lusk CH, Chazdon RL, and Hofmann G. 2006. A bounded null model explains juvenile tree community structure along light availability gradients in a temperate rain forest. Oikos 112:131-137.

Lusk CH, and Corcuera L. 2011. Effects of light availability and growth rate on leaf lifespan of four temperate rainforest Proteaceae. Revista Chilena de Historia Natural 84:269-277.

Lusk CH, Falster DS, Jara-Vergara CK, Jimenez-Castillo M, and Saldaña A. 2008a. Ontogenetic variation in light requirements of juvenile rainforest evergreens Functional Ecology 22:454-459. 10.1111/j.1365-2435.2008.01384.x.

Lusk $\mathrm{CH}$, Jorgensen MA, and Bellingham PJ. 2015. A conifer-angiosperm divergence in the growth vs. shade tolerance trade-off underlies the dynamics of a New Zealand warm-temperate rain forest. Journal of Ecology 103:479-488.

Lusk CH, Kooyman R, and Sendall K. 2011a. Latitude, solar elevation angles and gap-regenerating rain forest pioneers. Journal of Ecology 99:491-502.

Lusk CH, and Laughlin DC. 2017. Regeneration patterns, environmental filtering and tree species coexistence in a temperate forest. New Phytologist 213:657-668.

Lusk CH, Onoda Y, Kooyman R, and Gutiérrez-Girón A. 2010. Reconciling species-level versus plastic responses of evergreen leaf structure to light gradients: shade leaves punch above their weight. New Phytologist 186:429-438.

Lusk CH, Perez-Millaqueo MM, Piper FI, and Saldaña A. 2011b. Ontogeny, understorey light interception and simulated carbon gain of juvenile rainforest evergreens differing in shade tolerance. Annals of Botany 108 419-428. 
368

400

401

402

403

404 405

Lusk CH, and Piper FI. 2007. Seedling size influences relationships of shade tolerance with carbohydrate storage patterns in a temperate rainforest. Functional Ecology 21:78-86.

Lusk CH, Reich PB, Montgomery RA, Ackerly DA, and Cavender-Bares J. 2008b. Why are evergreen leaves so contrary about shade? Trends in Ecology \& Evolution 23:299-303.

Lusk CH, and Warton DI. 2007. Global meta-analysis shows that relationships of leaf mass per area with species shade tolerance depend on leaf habit and ontogeny. New Phytologist 176:764-774.

Martins EP. 2004. COMPARE, version 4.6b. Computer programs for the statistical analysis of comparative data. Distributed by the author at http://compare.bio.indiana.edu/. Department of Biology, Indiana University, Bloomington IN.

McGlone MS, Dungan RJ, Hall GMJ, and Allen RB. 2004. Winter leaf loss in the New Zealand woody flora. New Zealand Journal of Botany 42:1-19.

Nicholls J. 1991. Native forest. In: Clarkson BD, Smale MC, and Ecroyd CE, eds. Botany of Rotorua. Rotorua: Forest Research Institute, 15-22.

Poorter H, Niinemets Ü, Poorter L, Wright IJ, and Villar R. 2009. Causes and consequences of variation in leaf mass per area (LMA): a meta-analysis. New Phytologist 182:565-588. 10.1111/j.14698137.2009.02830.x.

Poorter L. 2009. Leaf traits show different relationships with shade tolerance in moist versus dry tropical forests. New Phytologist 181:890-900. doi:10.1111/j.1469-8137.2008.02715.x.

Poorter L, and Arets EJMM. 2003. Light environment and tree strategies in a Bolivian tropical moist forest: an evaluation of the light partitioning hypothesis. Plant Ecology 166:295-306.

Poorter L, and Bongers F. 2006. Leaf traits are good predictors of plant performance across 53 rain forest species. Ecology 87:1733-1743.

Pullar WA, Birrell KS, and Heine JC. 1973. Named tephras and tephra formations occurring in the Central North Island, with notes on derived soils and buried paleosols. New Zealand journal of geology and geophysics 16:497-518. 10.1080/00288306.1973.10431374.

Quinn GP, and Keough MJ. 2002. Experimental designs and data analysis for biologists. Cambridge: Cambridge University Press.

Reich PB, Uhl C, Walters MB, and Ellsworth DS. 1991. Leaf lifespan as a determinant of leaf structure and function among 23 Amazonian tree species. Oecologia 86:16-24.

Richardson SJ, Peltzer DA, Allen RB, and McGlone MS. 2010. Declining soil fertility does not increase leaf lifespan within species: evidence from the Franz Josef chronosequence, New Zealand. New Zealand Journal of Ecology 34:306-310.

Russo SE, and Kitajima K. 2016. The Ecophysiology of Leaf Lifespan in Tropical Forests: Adaptive and Plastic Responses to Environmental Heterogeneity. In: Goldstein G, and Santiago LS, eds. Tropical Tree Physiology: Adaptations and Responses in a Changing Environment. Cham: Springer International Publishing, 357-383.

Schneider CA, Rasband WS, and Eliceiri KW. 2012. NIH Image to ImageJ: 25 years of image analysis. Nat Meth 9:671-675. 
406

407

408

409

410

411

412

413

414

415

416

417

418

419

420

421

422

423

424

425

426

427

428

429

430

431

432

433

434

435

436

437

438
Sterck FJ, Poorter L, and Schieving F. 2006. Leaf traits determine the growth-survival trade-off across rain forest tree species. The American Naturalist 167:758-765. 10.1086/503056.

Stevens PF. 2001. Angiosperm Phylogeny Website. Version 14, July 2017 [and more or less continuously updated since]. Available at http://www.mobot.org/MOBOT/research/APweb/ (accessed October 2011.

Symonds MRE, and Blomberg SP. 2014. A Primer on Phylogenetic Generalised Least Squares. . In: Garamszegi L, ed. Modern Phylogenetic Comparative Methods and Their Application in Evolutionary Biology Berlin, Heidelberg: Springer, 105-130.

Urzua A, and Cassels BK. 1978. Alkaloid chemosystematics, chemotaxonomy and biogenesis in the Atherospermataceae. Lloydia 41:98-113.

van Gelder HA, Poorter L, and Sterck FJ. 2006. Wood mechanics, allometry, and life-history variation in a tropical rain forest tree community. New Phytologist 171:367-378.

van Ommen Kloeke AEE, Douma JC, Ordoñez JC, Reich PB, and van Bodegom PM. 2012. Global quantification of contrasting leaf life span strategies for deciduous and evergreen species in response to environmental conditions. Global Ecology and Biogeography 21:224-235. doi:10.1111/j.1466-8238.2011.00667.x.

Walters MB, and Reich PB. 1999. Low-light carbon balance and shade tolerance in the seedlings of woody plants: do winter deciduous and broad-leaved evergreen species differ? New Phytologist 143:143-154.

Wardle JA. 1984. The New Zealand Beeches: Ecology, Utilisation and Management. Christchurch: New Zealand Forest Service.

Williams K, Field CB, and Mooney HA. 1989. Relationships among leaf construction cost, leaf longevity, and light environments in rain-forest plants of the genus Piper. The American Naturalist 133:199-211.

Wright IJ, Reich PB, Westoby M, Ackerly DD, Baruch Z, Bongers F, Cavender-Bares J, Chapin T, Cornelissen JHC, Diemer M, Flexas J, Garnier E, Groom PK, Gulias J, Hikosaka K, Lamont BB, Lee T, Lee W, Lusk C, Midgley JJ, Navas ML, Niinemets U, Oleksyn J, Osada N, Poorter H, Poot P, Prior L, Pyankov VI, Roumet C, Thomas SC, Tjoelker MG, Veneklaas EJ, and Villar R. 2004. The worldwide leaf economics spectrum. Nature 428:821-827. 


\section{Table $\mathbf{1}$ (on next page)}

Study species, and minimum light requirements of their saplings.

Species' light requirements were estimated as the 10th percentile of the natural distribution of saplings in relation to canopy openness in temperate evergreen forest, Lake Okataina Scenic Reserve, New Zealand. $\mathrm{N}$ indicates the number of sampling points used to compute the light requirements of each species. 
1 Table 1. Study species and minimum light requirements of their saplings, estimated as the $10^{\text {th }}$

2 percentile of the natural distribution of saplings in relation to canopy openness in temperate evergreen

3 forest, Lake Okataina Scenic Reserve, New Zealand. N indicates the number of sampling points used to

4 compute the light requirements of each species.

\begin{tabular}{|c|c|c|c|c|}
\hline Species & Code & Family & $\begin{array}{c}\text { Typical } \\
\text { final height } \\
\text { (m) }\end{array}$ & $\begin{array}{l}\text { Minimum light } \\
\text { requirements (\% } \\
\text { canopy openness) }\end{array}$ \\
\hline Beilschmiedia tawa & Beitaw & Lauraceae & 30 & $0.8(n=72)$ \\
\hline Litsea calicaris & Litcal & Lauraceae & 30 & $1.3(n=43)$ \\
\hline Hedycarya arborea & Hedarb & Monimiaceae & 12 & $1.1(n=84)$ \\
\hline Laurelia novae-zelandiae & Launov & Atherospermataceae & 35 & $1.4(n=92)$ \\
\hline Knightia excelsa & Kniexc & Proteaceae & 35 & $1.1(n=105)$ \\
\hline Aristotelia serrata & Ariser & Elaeocarpaceae & 10 & $3.7(n=23)$ \\
\hline Elaeocarpus dentatus & Eladen & Elaeocarpaceae & 20 & $1.7(n=29)$ \\
\hline Weinmannia racemosa & Weirac & Cunoniaceae & 25 & $1.7(n=27)$ \\
\hline Alectryon excelsus & Aleexc & Sapindaceae & 20 & $1.5(n=20)$ \\
\hline Melicytus ramiflorus & Melram & Violaceae & 10 & $1.9(n=50)$ \\
\hline Myrsine australis & Myraus & Primulaceae & 6 & $1.8(n=28)$ \\
\hline Geniostoma ligustrifolium & Genlig & Loganiaceae & 3 & $1.9(n=53)$ \\
\hline Coprosma grandifolia & Copgra & Rubiaceae & 6 & $1.6(n=104)$ \\
\hline Coprosma robusta & Coprob & Rubiaceae & 6 & $4.2(n=29)$ \\
\hline Brachyglottis repanda & Brarep & Asteraceae & 6 & $3.3(n=15)$ \\
\hline Carpodetus serratus & Carser & Rousseaceae & 10 & $2.6(n=62)$ \\
\hline Pseudopanax arboreus & Psearb & Araliaceae & 8 & $2.2(n=18)$ \\
\hline Schefflera digitata & Schdig & Araliaceae & 8 & $1.9(n=35)$ \\
\hline Pittosporum tenuifolium & Pitten & Pittosporaceae & 8 & $3.5(n=19)$ \\
\hline
\end{tabular}

5

6 


\section{Table 2 (on next page)}

Leaf traits of temperate evergreen saplings growing in gap and understorey environments, Lake Okataina Scenic Reserve, New Zealand.

Values show means ( \pm 1 SD. Species codes are given in Table 1 . 
1 Table 2. Mean leaf trait values ( \pm 1 SD) of temperate evergreen saplings growing in gap and understorey environments, Lake Okataina Scenic

2 Reserve, New Zealand. Species codes are given in Table 1. nd = no data.

\begin{tabular}{|c|c|c|c|c|c|c|c|c|c|c|c|c|c|c|c|c|c|c|}
\hline \multirow{2}{*}{$\begin{array}{l}\text { Species } \\
\text { Aleexc }\end{array}$} & \multirow{2}{*}{$\begin{array}{l}\text { Light } \\
\text { Gap }\end{array}$} & \multirow{2}{*}{$\begin{array}{c}\text { Canopy openness } \\
\text { (\%) above trait } \\
\text { measurements } \\
12.2-20.8\end{array}$} & \multicolumn{3}{|c|}{$\begin{array}{l}\text { Dry matter } \\
\text { content (\%) }\end{array}$} & \multicolumn{3}{|c|}{$\begin{array}{c}\text { Leaf mass per } \\
\text { area }\left(\mathrm{g} \mathrm{m}^{-2}\right)\end{array}$} & \multicolumn{3}{|c|}{$\begin{array}{l}\text { Density } \\
\left(\mathrm{g} \mathrm{cm}^{-3}\right)\end{array}$} & \multicolumn{3}{|c|}{$\begin{array}{c}\text { Thickness } \\
\text { (mm) }\end{array}$} & \multicolumn{3}{|c|}{$\begin{array}{c}\text { Life lifespan } \\
(y r)\end{array}$} & \multirow{2}{*}{$\begin{array}{l}\mathrm{N} \\
(\%) \\
2.2\end{array}$} \\
\hline & & & 46.7 & \pm & 3.3 & 88.7 & \pm & 8.4 & 0.45 & \pm & 0.08 & 0.21 & \pm & 0.02 & 2.4 & \pm & 2.0 & \\
\hline Aleexc & Shade & $1.3-2.6$ & 43.1 & \pm & 3.5 & 55.6 & \pm & 3.3 & 0.49 & \pm & 0.06 & 0.13 & \pm & 0.02 & 3.5 & \pm & 1.5 & 2.2 \\
\hline Ariser & Gap & $13.0-23.1$ & 29.2 & \pm & 3.1 & 50.2 & \pm & 27.8 & 0.22 & \pm & 0.03 & 0.24 & \pm & 0.06 & 0.6 & \pm & 0.1 & 2.2 \\
\hline Ariser & Shade & $2.1-2.6$ & 25.2 & \pm & 2.7 & 33.8 & \pm & 5.8 & 0.23 & \pm & 0.02 & 0.15 & \pm & 0.02 & 0.7 & \pm & 0.0 & 2.8 \\
\hline Beitaw & Gap & $12.8-22.2$ & 42.8 & \pm & 1.1 & 100.0 & \pm & 22.9 & 0.43 & \pm & 0.04 & 0.23 & \pm & 0.03 & 2.3 & \pm & 1.4 & 1.6 \\
\hline Beitaw & Shade & $1.3-2.4$ & 40.7 & \pm & 3.3 & 74.4 & \pm & 5.2 & 0.44 & \pm & 0.04 & 0.17 & \pm & 0.00 & 3.8 & \pm & 1.5 & 1.5 \\
\hline Brarep & Gap & $13.4-23.7$ & 30.1 & \pm & 2.7 & 83.7 & \pm & 7.4 & 0.29 & \pm & 0.07 & 0.31 & \pm & 0.07 & 1.1 & \pm & 0.1 & 1.5 \\
\hline Brarep & Shade & $1.5-2.8$ & 22.1 & \pm & 2.4 & 45.7 & \pm & 10.5 & 0.20 & \pm & 0.03 & 0.23 & \pm & 0.01 & 1.4 & \pm & 0.2 & 1.9 \\
\hline Carser & Gap & $11.6-22.8$ & 29.9 & \pm & 4.5 & 59.1 & \pm & 14.8 & 0.25 & \pm & 0.06 & 0.23 & \pm & 0.03 & 1.1 & \pm & 0.5 & 2.2 \\
\hline Carser & Shade & $1.5-2.6$ & 24.6 & \pm & 3.7 & 29.6 & \pm & 1.9 & 0.26 & \pm & 0.03 & 0.11 & \pm & 0.02 & 2.2 & \pm & 0.7 & 2.2 \\
\hline Copgra & Gap & $12.2-18.8$ & 24.8 & \pm & 4.8 & 68.7 & \pm & 10.2 & 0.20 & \pm & 0.01 & 0.35 & \pm & 0.04 & 1.4 & \pm & 0.3 & 2.2 \\
\hline Copgra & Shade & $1.2-2.3$ & 21.5 & \pm & 1.5 & 47.6 & \pm & 16.5 & 0.17 & \pm & 0.03 & 0.28 & \pm & 0.04 & 2.5 & \pm & 0.9 & 1.9 \\
\hline Coprob & Gap & $12.0-28.8$ & 27.4 & \pm & 5.4 & 71.5 & \pm & 12.3 & 0.23 & \pm & 0.02 & 0.32 & \pm & 0.05 & 1.1 & \pm & 0.3 & 1.7 \\
\hline Coprob & Shade & nd & nd & & & nd & & & nd & & & nd & & & nd & & & nd \\
\hline Eladen & Gap & $13.0-19.3$ & 39.1 & \pm & 6.6 & 78.2 & \pm & 14.8 & 0.32 & \pm & 0.03 & 0.24 & \pm & 0.04 & 1.5 & \pm & 0.3 & 1.5 \\
\hline Eladen & Shade & $1.3-2.6$ & 35.6 & \pm & 3.5 & 42.4 & \pm & 2.0 & 0.28 & \pm & 0.04 & 0.15 & \pm & 0.02 & 2.2 & \pm & 1.1 & 1.6 \\
\hline Genlig & Shade & $1.4-2.9$ & 15.2 & \pm & 1.8 & 33.4 & \pm & 2.7 & 0.12 & \pm & 0.02 & 0.28 & \pm & 0.04 & 1.7 & \pm & 0.6 & 1.9 \\
\hline Genrup & Gap & $12.8-21.1$ & 20.1 & \pm & 2.2 & 64.3 & \pm & 6.2 & 0.18 & \pm & 0.02 & 0.35 & \pm & 0.07 & 1 & \pm & 0.2 & 1.6 \\
\hline Hedarb & Gap & $12.2-18.2$ & 24.0 & \pm & 2 & 71.6 & \pm & 25.2 & 0.19 & \pm & 0.04 & 0.37 & \pm & 0.1 & 2 & \pm & 0.6 & 2.7 \\
\hline Hedarb & Shade & $1.3-2.5$ & 22.4 & \pm & 2.6 & 58.3 & \pm & 5.3 & 0.19 & \pm & 0.03 & 0.31 & \pm & 0.02 & 5.8 & \pm & 2.8 & 2.9 \\
\hline
\end{tabular}




\begin{tabular}{|c|c|c|c|c|c|c|c|c|c|c|c|c|c|c|c|c|c|c|}
\hline Kniexc & Gap & $12.8-25.6$ & 42.6 & \pm & 1.8 & 106.5 & \pm & 47.1 & 0.31 & \pm & 0.03 & 0.34 & \pm & 0.1 & 3.8 & \pm & 2.2 & 0.9 \\
\hline Kniexc & Shade & $1.3-2.6$ & 41.5 & \pm & 2.2 & 75.6 & \pm & 2.9 & 0.37 & \pm & 0.02 & 0.21 & \pm & 0.02 & 7.7 & \pm & 5.4 & 1.3 \\
\hline Launov & Gap & $12.8-18.2$ & 25.2 & \pm & 4.3 & 83.5 & \pm & 25.6 & 0.2 & \pm & 0.03 & 0.37 & \pm & 0.06 & 1.9 & \pm & 0.4 & 1.8 \\
\hline Launov & Shade & $1.3-2.8$ & 25.0 & \pm & 3 & 56.6 & \pm & 11.7 & 0.19 & \pm & 0.02 & 0.3 & \pm & 0.05 & 4.6 & \pm & 1.5 & 2.4 \\
\hline Litcal & Gap & $12.8-18.2$ & 32.6 & \pm & 5.3 & 83.1 & \pm & 16.2 & 0.28 & \pm & 0.06 & 0.26 & \pm & 0.04 & 2.3 & \pm & 0.9 & 1.6 \\
\hline Litcal & Shade & $1.3-2.9$ & 27.8 & \pm & 3.4 & 59.8 & \pm & 8.5 & 0.27 & \pm & 0.04 & 0.22 & \pm & 0.01 & 3.9 & \pm & 1.8 & 1.8 \\
\hline Melram & Gap & $12.2-25.6$ & 26.6 & \pm & 4.9 & 73.4 & \pm & 24.4 & 0.25 & \pm & 0.04 & 0.29 & \pm & 0.05 & 1.1 & \pm & 0.2 & 2.4 \\
\hline Melram & Shade & $1.4-2.6$ & 22.1 & \pm & 2.5 & 45.0 & \pm & 5.0 & 0.19 & \pm & 0.01 & 0.24 & \pm & 0.02 & 1.7 & \pm & 0.5 & 2.7 \\
\hline Myraus & Gap & $12.5-27.8$ & 33.8 & \pm & 0.9 & 83.7 & \pm & 1.0 & 0.28 & \pm & 0.03 & 0.3 & \pm & 0.02 & 1.6 & \pm & 0.4 & 1.2 \\
\hline Myraus & Shade & $1.6-2.8$ & 30.3 & \pm & 2.2 & 56.0 & \pm & 2.7 & 0.25 & \pm & 0.04 & 0.23 & \pm & 0.05 & 2.5 & \pm & 0.9 & 1.2 \\
\hline Pitten & Gap & $12.8-27.5$ & 37.0 & \pm & 6.7 & 75.2 & \pm & 27.7 & 0.36 & \pm & 0.05 & 0.21 & \pm & 0.05 & 1.6 & \pm & 0.6 & 1.7 \\
\hline Pitten & Shade & $1.5-2.9$ & 29.6 & \pm & 5.3 & 41.7 & \pm & 5.0 & 0.31 & \pm & 0.04 & 0.14 & \pm & 0.02 & 1.8 & \pm & 0.7 & 1.8 \\
\hline Psearb & Gap & $14.0-25.2$ & 32.2 & \pm & 1.2 & 113.8 & \pm & 25.8 & 0.24 & \pm & 0.03 & 0.49 & \pm & 0.05 & 1.3 & \pm & 0.3 & 1.6 \\
\hline Psearb & Shade & $1.4-2.4$ & 25.6 & \pm & 2.5 & 65.4 & \pm & 4.4 & 0.19 & \pm & 0.03 & 0.34 & \pm & 0.03 & 2.2 & \pm & 0.5 & 1.6 \\
\hline Schdig & Gap & $13.2-18.8$ & 25.4 & \pm & 3.3 & 75.8 & \pm & 8.2 & 0.25 & \pm & 0.01 & 0.3 & \pm & 0.03 & 1.1 & \pm & 0.2 & 2.1 \\
\hline Schdig & Shade & $1.2-2.6$ & 18.5 & \pm & 2.0 & 35.2 & \pm & 2.4 & 0.17 & \pm & 0.01 & 0.21 & \pm & 0.01 & 1.9 & \pm & 0.4 & 3 \\
\hline Weirac & Gap & $12.0-24.6$ & 36.2 & \pm & 2.3 & 103.3 & \pm & 31.0 & 0.32 & \pm & 0.05 & 0.33 & \pm & 0.05 & 2.7 & \pm & 1.7 & 1.5 \\
\hline Weirac & Shade & $1.3-2.4$ & 34.1 & \pm & 3.6 & 71.9 & \pm & 8.3 & 0.32 & \pm & 0.02 & 0.22 & \pm & 0.04 & 3.2 & \pm & 1.3 & 1.3 \\
\hline
\end{tabular}




\section{Table 3 (on next page)}

Summary of nested ANOVA testing the effects of light environment (gap versus shade) and species on leaf traits.

$\mathrm{N}=4-6$ of each species in each light environment. Light environment was nested within species, as species were not all compared in common plots. Coprosma robusta was omitted from ANOVA, as leaf traits of this species were available only from gaps. 
1 Table 3. Summary of nested ANOVA testing the effects of light environment (gap versus shade) and

2 species on leaf traits ( $n=4-6$ of each species in each light environment). Light environment was nested

3 within species, as species were not all compared in common garden plots. Coprosma robusta was

4 omitted from ANOVA, as leaf traits of this species were available only from gaps.

(a) $\log ($ LMA)

\begin{tabular}{llrrrc}
\hline Effect & SS & df & MS & F & p \\
\hline Intercept & 548.1 & 1 & 548.1 & 67465 & $<0.0001$ \\
Species & 1.712 & 17 & 0.101 & 12.39 & $<0.0001$ \\
Light(Species) & 1.805 & 18 & 0.1003 & 12.34 & $<0.0001$ \\
Error & 1.162 & 143 & 0.0081 & & \\
\hline
\end{tabular}

(b) $\log$ (Density)

\begin{tabular}{lrrrrr}
\hline Effect & \multicolumn{1}{c}{ SS } & df & \multicolumn{1}{c}{ MS } & \multicolumn{1}{c}{ F } & \multicolumn{1}{c}{ p } \\
\hline Intercept & 61.56 & 1 & 61.56 & 6563 & $<0.0001$ \\
Species & 2.923 & 17 & 0.1719 & 18.33 & $<0.0001$ \\
Light(Species) & 0.2755 & 18 & 0.01530 & 1.632 & 0.0595 \\
Error & 1.341 & 143 & 0.00938 & & \\
\hline
\end{tabular}

(c) $\log$ (Thickness)

\begin{tabular}{lrrrrc}
\hline Effect & \multicolumn{1}{c}{ SS } & df & \multicolumn{1}{c}{ MS } & \multicolumn{1}{c}{ F } & p \\
\hline Intercept & 64.08 & 1 & 64.08 & 10901 & $<0.0001$ \\
Species & 2.410 & 17 & 0.1418 & 24.12 & $<0.0001$ \\
Light(Species) & 1.105 & 18 & 0.06138 & 10.44 & $<0.0001$ \\
Error & 0.8405 & 143 & 0.00588 & & \\
\hline
\end{tabular}

(d) Dry matter content

\begin{tabular}{lrrrrc}
\hline Effect & \multicolumn{1}{c}{ SS } & df & \multicolumn{1}{c}{ MS } & \multicolumn{1}{l}{ F } & p \\
\hline Intercept & 154683 & 1 & 154683 & 12414 & $<0.0001$ \\
Species & 9585.4 & 17 & 563.8 & 45.25 & $<0.0001$ \\
Light(Species) & 869.8 & 18 & 48.3 & 3.878 & $<0.0001$ \\
Error & 1781.8 & 143 & 12.5 & & \\
\hline
\end{tabular}

(e) $\log ($ Leaf lifespan)

\begin{tabular}{lcrrrc}
\hline Effect & SS & df & \multicolumn{1}{c}{ MS } & F & p \\
\hline Intercept & 13.04 & 1 & 13.04 & 454.8 & $<0.0001$ \\
Species & 5.611 & 17 & 0.3300 & 11.51 & $<0.0001$ \\
Light(Species) & 2.592 & 18 & 0.144 & 5.023 & $<0.0001$ \\
Error & 3.984 & 139 & 0.02866 & & \\
\hline
\end{tabular}




\section{Table 4 (on next page)}

Correlations among sapling light requirements (MLR) and leaf traits of 19 temperate evergreens, New Zealand.

Values to the lower left of the diagonal show Pearson cross-species correlations; results from phylogenetic least squares regression appear to the upper right. $*=P<0.05,{ }^{* *}=P<0.01$. Only 18 species were sampled in the shade, as not enough Coprosma robusta saplings could be located in the understorey. 
1 Table 4. Correlations among sapling light requirements (MLR) and leaf traits of 19 temperate

2 evergreens, New Zealand; only 18 species were sampled in the shade. Values to the lower left of the

3 diagonal show Pearson cross-species correlations; results from phylogenetic least squares regression

4 appear to the upper right. ${ }^{*}=\mathrm{P}<0.05,{ }^{* *}=\mathrm{P}<0.01$.

5 (a) Sun leaves (gaps)

\begin{tabular}{|c|c|c|c|c|c|c|c|}
\hline & $(\log ) M L R$ & $(\log )$ LMA & $\begin{array}{c}\text { (log) } \\
\text { Thickness }\end{array}$ & $\begin{array}{c}(\log ) \\
\text { Density }\end{array}$ & DMC & $(\log ) N$ & $(\log ) \mathrm{LL}$ \\
\hline (log)MLR & & -0.41 & 0.00 & -0.24 & -0.26 & 0.12 & $-0.73^{* *}$ \\
\hline$(\log )$ LMA & $-0.47^{*}$ & & 0.36 & 0.00 & $0.54^{*}$ & $-0.58^{\star *}$ & $0.71^{* *}$ \\
\hline (log)Thickness & -0.12 & 0.33 & & $-0.59^{\star *}$ & 0.00 & -0.15 & 0.07 \\
\hline (log)Density & -0.23 & $0.53^{*}$ & $-0.59^{\star *}$ & & $0.93^{* *}$ & 0.00 & $0.52^{*}$ \\
\hline DMC & -0.30 & $0.57^{*}$ & $-0.48^{*}$ & $0.93^{\star *}$ & & $-0.46^{*}$ & 0.00 \\
\hline$(\log ) N$ & 0.14 & $-0.57^{*}$ & -0.14 & -0.33 & -0.44 & & $-0.50^{*}$ \\
\hline$(\log ) \mathrm{LL}$ & $-0.74^{* *}$ & $0.74^{* *}$ & 0.06 & $0.51^{*}$ & $0.60^{* *}$ & -0.45 & \\
\hline
\end{tabular}

6 (b) Shade leaves (understorey)

\begin{tabular}{llcccccc}
\hline & & \multicolumn{2}{c}{$(\log )$} & $(\log )$ & & & \\
& $(\log )$ MLR & $(\log ) L M A$ & Thickness & Density & DMC & $(\log ) \mathbf{N}$ & $(\log )$ LL \\
\hline$(\log )$ MLR & & $-0.65^{* *}$ & 0.00 & -0.31 & -0.44 & 0.33 & $-0.83^{* *}$ \\
$(\log )$ LMA & $-0.66^{* *}$ & & 0.36 & 0.00 & $0.61^{* *}$ & $-0.70^{* *}$ & $0.72^{* *}$ \\
$(\log )$ Thickness & -0.24 & 0.34 & & $-0.65^{* *}$ & 0.00 & -0.02 & 0.23 \\
$(\log )$ Density & -0.32 & $0.49^{*}$ & $-0.65^{* *}$ & & $0.95^{* *}$ & 0.00 & 0.36 \\
DMC & -0.44 & $0.61^{* *}$ & $-0.49^{*}$ & $0.95^{* *}$ & & $-0.61^{* *}$ & 0.00 \\
$(\log ) \mathbf{N}$ & 0.23 & $-0.55^{*}$ & -0.02 & -0.43 & $-0.55^{*}$ & & $-0.50^{*}$ \\
$(\log ) \mathrm{LL}$ & $-0.84^{* *}$ & $0.73^{* *}$ & 0.22 & 0.38 & $0.48^{*}$ & -0.30 & \\
\hline
\end{tabular}


Figure $\mathbf{1}$ (on next page)

Relationships among leaf traits and minimum light requirements of 19 temperate forest evergreens.

Gap and understorey data are shown by open and filled (black) symbols, respectively. Solid lines show relationships significant at $\mathrm{P}=0.05$; correlation coefficients appear in Table 4 . 

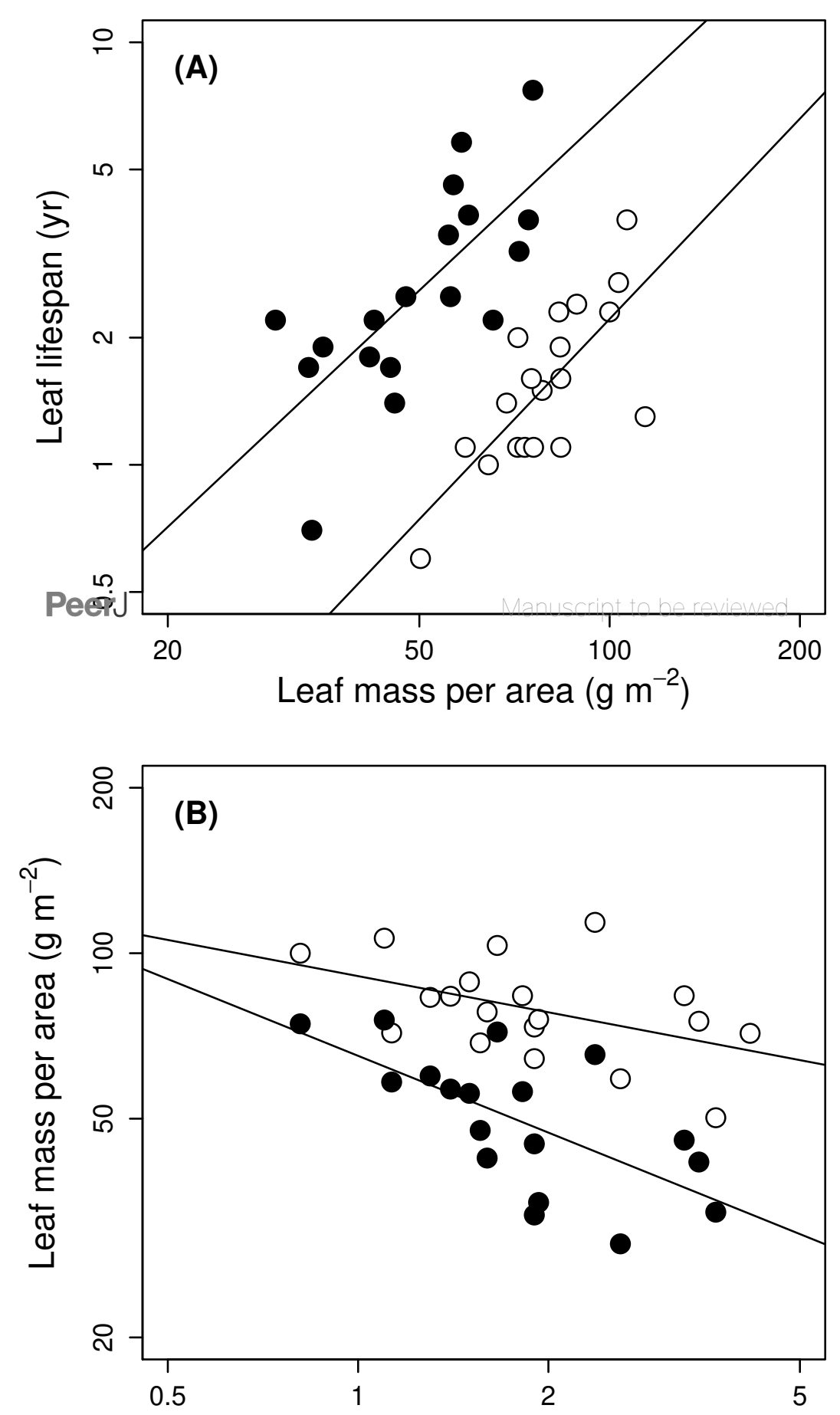

Min. light requirements (\% canopy openness)

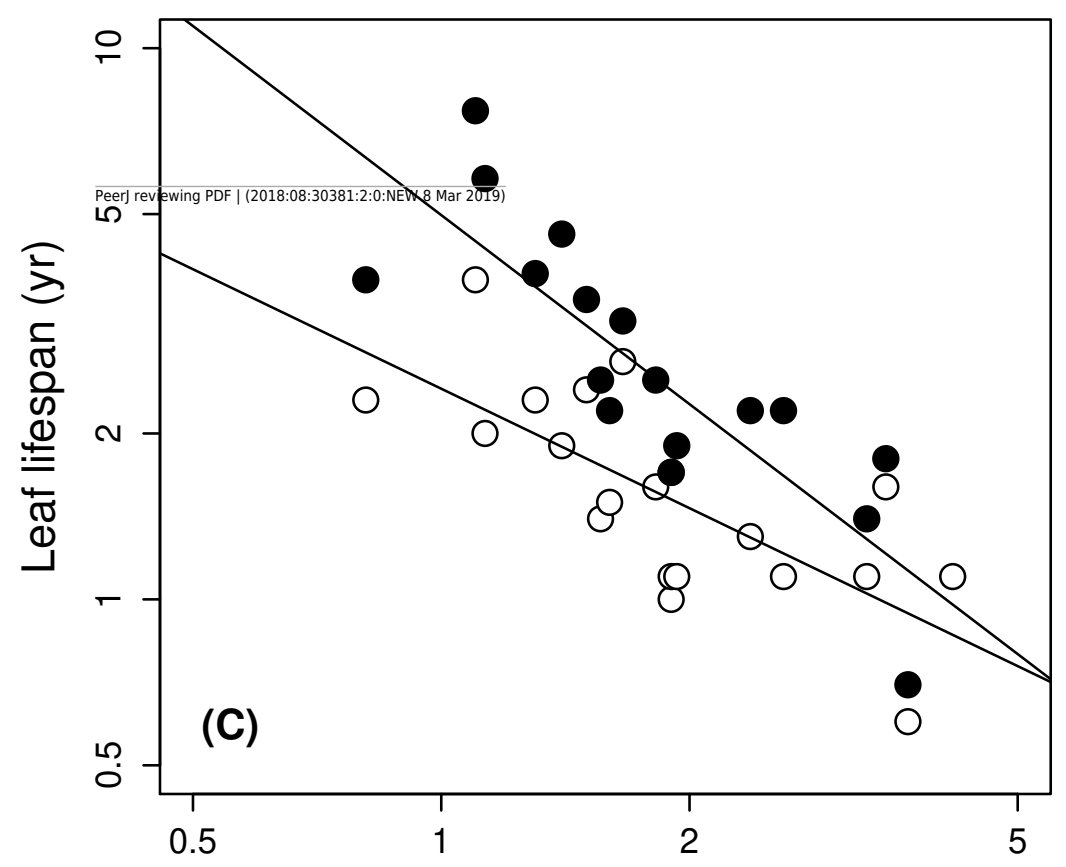

Min. light requirements (\% canopy openness) 